\title{
Selecting the Right Type of Educational Experience for Your Agritourism Operation ${ }^{1}$
}

\author{
Joy N. Rumble, Kathryn Stofer, and Hoda Manafian²
}

\section{Introduction}

With less than two percent of the American population directly involved in agriculture (American Farm Bureau Federation, 2017), few Americans get information about the agriculture industry through their work or residence. Therefore, agritourism has become a way for consumers to experience agriculture and for the industry to increase agricultural awareness. Nostalgia and inquisitiveness attract the public to agritourism activities (farm stays, harvest festivals, u-pick operations, wine tasting, horseback riding, corn mazes, and others). Agritourism operators can add remarkable value to their operations by incorporating educational opportunities (Arroy, Barbieri, \& Rich, 2013). However, the educational opportunities must appeal to the agritourism visitors and match their preferences for communication and education. This article was informed by focus group research with agritourism visitors and will discuss educational opportunities that can be incorporated into your agritourism operation. Throughout this document, examples will be given in reference to a fictitious strawberry u-pick operation; however, the activities could be altered to match any operation.

This is one of several documents supporting agritourism in the state of Florida. One EDIS document, Helping Agritourism Visitors Learn During their Visits, outlines an overall process for planning educational experiences by understanding your visitor needs and your own goals and resources. Once you have set your goals, use this document to determine the right type of experience to meet those goals. Here we outline two basic strategies: self-exploration and guided or facilitated activities.

\section{Self-Exploration}

Many agritourism visitors like the opportunity to explore the operation on their own and at their own pace. The lack of interaction with self-explorers can make it easy to overlook educational opportunities; however, there are many things that you can do to increase agricultural awareness among your visitors who self-explore.

\section{Educational Guide}

One strategy is to supplement self-guided exploration with an educational guide. These guides could be printed handouts that visitors can take home, reusable handouts to be left at the site, or web-based guides that can be accessed anytime. The educational guide could include a map and/or fun facts about the operation. To promote deeper engagement, the guides can even incorporate questions designed to help visitors think about why certain aspects of the operation happen the way they do (but try to avoid yes or no questions, and be sure to provide answers somewhere). Additionally, a scavenger hunt could be incorporated into the educational guide. An example of a scavenger hunt can be found in Figure 1.

1. This document is AEC641, one of a series of the Department of Agricultural Education and Communication, UF/IFAS Extension. Original publication date May 2018. Visit the EDIS website at http://edis.ifas.ufl.edu.

2. Joy N. Rumble, assistant professor, Department of Agricultural Education and Communication; Kathryn Stofer, research assistant professor, Department of Agricultural Education and Communication; and Hoda Manafian, doctoral student, Department of Tourism, Recreation, and Sports Management; UF/IFAS Extension, Gainesville, FL 32611.

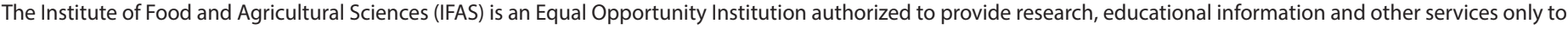

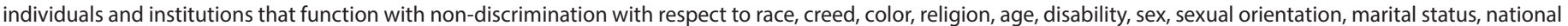
origin, political opinions or affiliations. For more information on obtaining other UF/IFAS Extension publications, contact your county's UF/IFAS Extension office. 


\section{Discover Something Sweet}

Complete the scavenger hunt below by finding the clues throughout the farm. Take your completed sheet to the check out to get \$1 off your u-pick purchase.

1. How many seeds are on the outside of a strawbern?

2. Strawberry shortcake originated from who?

3. What city is the winter strawberry capital of the world?

4. Strawberries taste best at what temperature?

5. Strawberries are high in what vitamin?

6. Take a selfie picking strawberries and tag sweet berries on instagram, twitter, or facebook to get an additional \$1 off your purchase.

\section{Sweet Berries
U-gick}

Figure 1. Scavenger hunt example.

\section{Placards and Displays}

Incorporating educational placards or small displays throughout the operation can also increase agricultural awareness of the self-explorer. This can be as simple as labeling plants and farm equipment or as complex as including displays with information or even interactive displays. Figure 2 provides an example of a sign that could label the strawberry variety at the end of a row. Figure 3 provides an example of an informational display that could be strategically placed in the farm. The display could be made interactive by having a station set up with fresh strawberries and magnifying glasses for visitors to count the number of seeds on a strawberry.

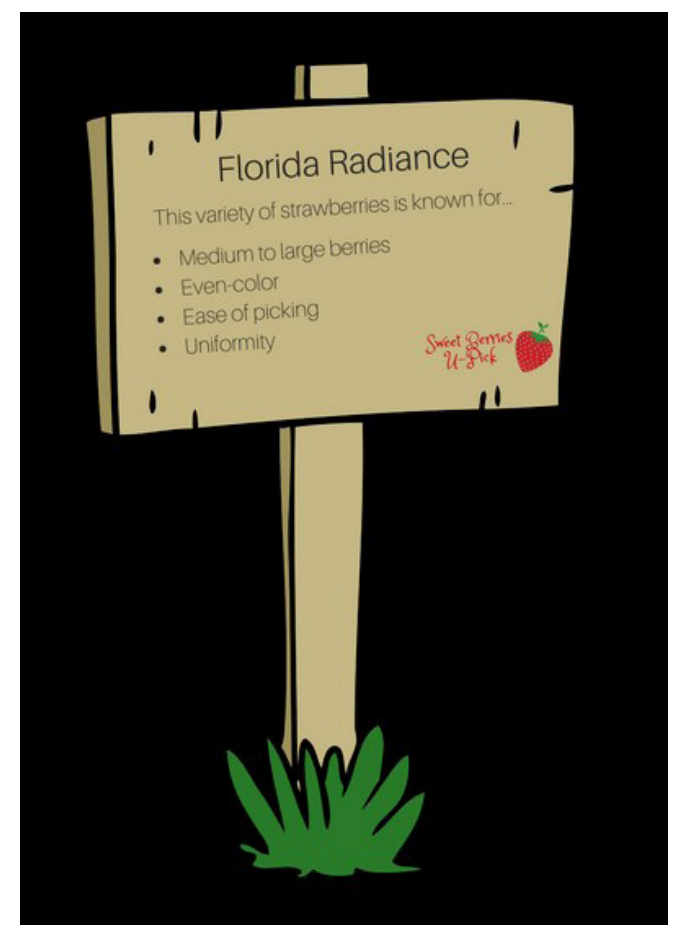

Figure 2. Example of wording that could be placed on a sign to identify a strawberry variety.

\section{Discover Something Sweet}

Did you know...

Each strawberry has around
200 seeds. Strawberries are
the only fruit that has seeds
on the outside.
Grab a magnifying glass and
see if you can count the
seeds!

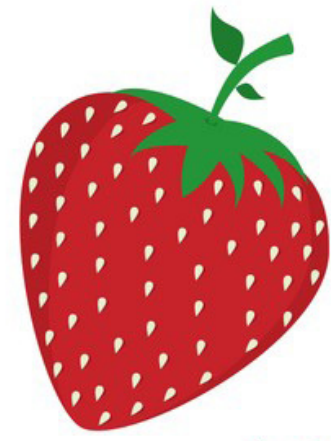

Sweet ßem
Figure 3. Example of wording that could be used for an informational display.

\section{Audio Tours}

Audio tours are popular in museums and parks and could be utilized in agritourism as well. Dial and discover tours have become popular, such as the ones for Visit Gainesville (See Figures 4 and 5). Instead of a map and audio tour of a local area like Gainesville, you could create one for your agritourism operation. There are several new smartphone apps that allow you to create audio tours. VoiceMap and My Tours are two examples.

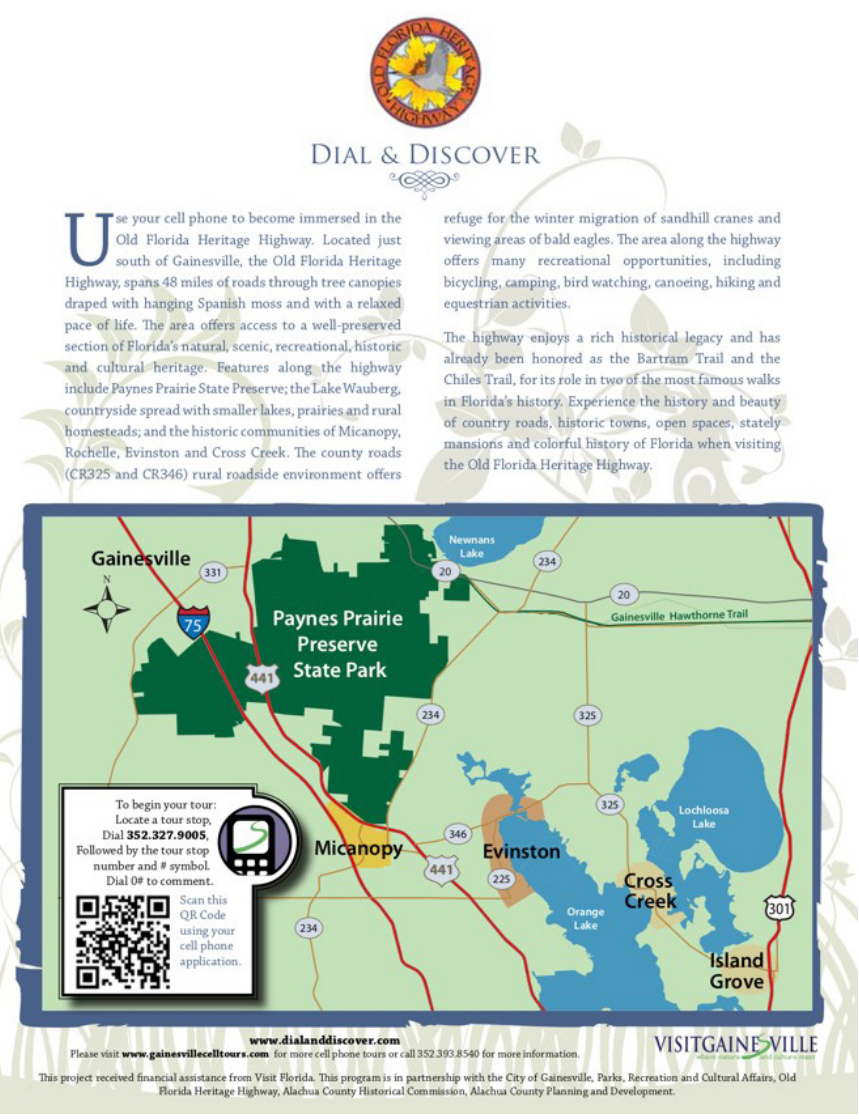

Figure 4. Example of audio tour system provided by VisitGainesville. Credits: Gainesville Florida Visitors \& Convention Bureau, 2018 


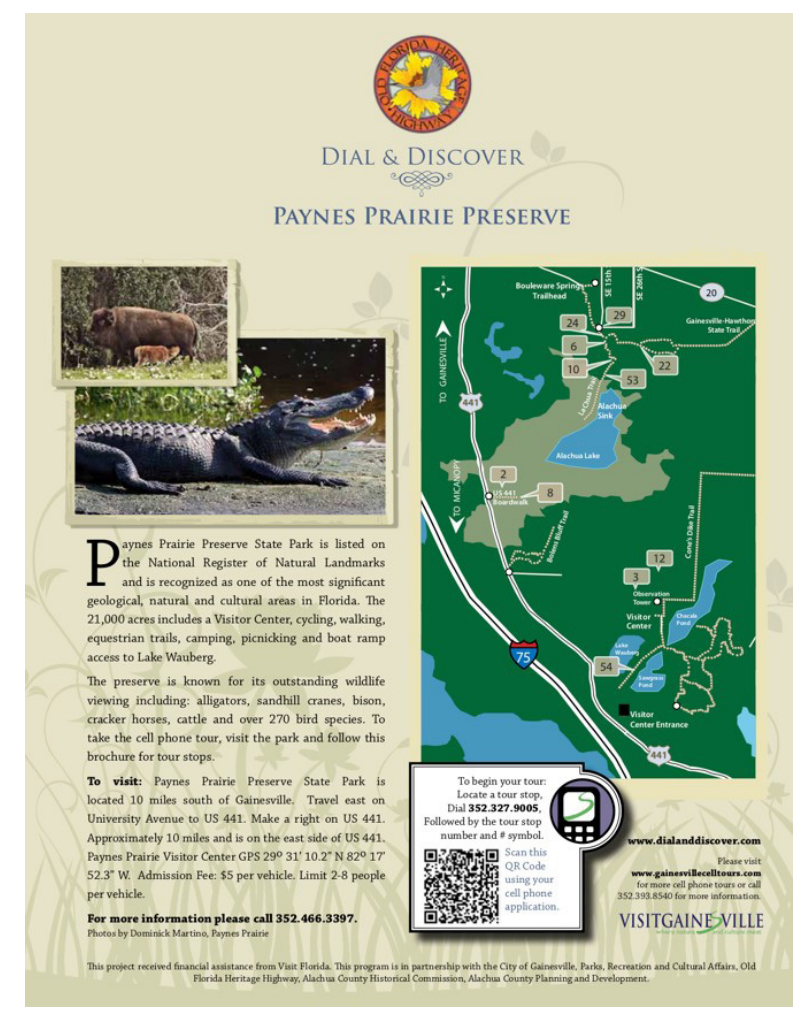

Figure 5. Example of audio tour for Paynes Prairie provided by VisitGainesville.

Credits: Gainesville Florida Visitors \& Convention Bureau, 2018

\section{Guided Exploration}

On the other hand, some agritourism visitors value guided exploration. An agritourism visitor we talked to said, "Without guidance, it would be difficult to know what to look at." Guided explorations can be facilitated by venue operators, workers, or volunteers, and these explorations can take many forms.

\section{Guided Tours}

Whether in a wagon pulled by a tractor or walking behind a tour guide, some visitors value the opportunity to participate in a guided tour. If you are going to offer guided tours on your operations, signage should clearly articulate the starting point and time and whether there is an additional cost to participate in the guided tour. You should consider the number of people included in each tour as well as the length of the tour. During the tour, the tour guide should provide educational and unique facts about the operation, the land, and the crops/livestock on your operations. Again, using open-ended questions can help visitors recognize their own current understanding and potentially engage them more than simply sharing information. Historical and observational commentary can also be included. For more information on best practices for farm tours, see the EDIS document Planning for a Farm Tour: Keeping the Conversation Fresh.

\section{Presentations and Demonstrations}

Guided exploration can also be facilitated through the use of presentations and demonstrations. Some visitors like the opportunity to learn through presentation or demonstration, and one visitor we talked to said, "That's why you go, for people to tell you things." Presentations and demonstrations can vary in length and formality. An example presentation might include the history of the farm and agriculture in the county, especially compared to other counties, states, or other commodities. A demonstration may include how to pick strawberries, how to preserve strawberries, or how to make a favorite strawberry recipe. The agritourism visitors we talked to cautioned against making presentations or demonstrations too long. They mentioned that 30 minutes was the longest they would sit for presentation or demonstration, but shorter 5-10 minute presentations or demonstrations were favorable.

\section{Informal Discussions}

The agritourism visitors we talked to during our research expressed value in talking with a person associated with the operation (owners/workers or other volunteers). Another visitor said, "It'd be helpful to have somebody explain to you what it is you're looking at and how it got there.... What not to touch, do not eat this." To capitalize on informal discussions, it is recommended that you have representatives at key points throughout the operation, as well as floaters who can help visitors and provide information as needed. Encourage and train your workers to offer educational information when interacting with visitors. For more information, see EDIS document Education and Facilitation Methods for Extension.

\section{Take-Home Resources}

Many visitors we talked to said they like to continue learning and exploring once they get home. In addition, many liked sharing with their friends and family what they learned. These visitors wanted take-home resources so they could learn more and share what they have learned. These resources could include handouts on the operation, how to grow strawberries, history of Florida's strawberry industry, strawberry recipe cards, etc. Printed handouts should include your operation's name and logo, as well as contact information. Resources for additional at-home learning can also be shared on your website and/or social media. A final suggestion is for take-home materials is non-paper takeaways, such as seeds or purchased products (including plants and seedlings), or value-added products. When possible, these takeaways should be branded with 
your operation's name and logo. These can be powerful advertising tools.

\section{Variability in Opportunities}

The visitors we talked to valued a variety of educational opportunities while visiting agritourism operations and were interested in having options. One participant described the importance of variety and said, "I love having the choice like to go to a place and say, 'Okay I could do this over here or I could do this over here and I can choose what I'm interested in. Like, am I interested in avocado growing or am I interested in aloe vera? Am I interested in herbs as medicine?' Whatever it is, I'd love to be able to choose those." Variety in the educational opportunities that you offer is also important in order to reach different audiences that may be visiting your farm. Consider the various ages of the participants, and tailor your programming accordingly. For example, for children, you may consider programs that are hands-on, short, and activity-based. Older visitors may be interested in the history of the farm and how to grow or use certain crops. Offering a variety of opportunities over time can also encourage repeat visitors who come back for a new experience.

\section{Conclusion}

Several educational opportunities for your agritourism operation have been discussed in this document. Select an opportunity(ies) that is right for your operation and give it a try. Even small efforts to incorporate education into your operation can help to improve agricultural awareness. Creating an educational experience at your operation can make visitors' experiences more informative and appealing while adding value to their visit. Additionally, you can increase visitors' satisfaction and, consequently, the income of your agritourism operation.

\section{References}

Arroyo, C. G., Barbieri, C., \& Rich, S. R. (2013). Defining agritourism: A comparative study of stakeholders' perceptions in Missouri and North Carolina. Tourism Management, 37, 39-47.

American Farm Bureau Federation. (2017). Fast Facts About Agriculture-The Voice of Agriculture. American Farm Bureau Federation. Retrieved from http://www. fb.org/newsroom/fast-facts
Gainesville Florida Visitors \& Convention Bureau. (2018). Dial and Discover Cell Phone Tour. Retrieved from http:// www.visitgainesville.com/media/890858/dialdiscovermainmap.pdf

Gainesville Florida Visitors \& Convention Bureau. (2018). Dial and Discover Cell Phone Tour. Retrieved from http:// www.visitgainesville.com/media/890861/paynesprairie.pdf 